\title{
Should Jurists Take Interests More Seriously?
}

\author{
Geoffrey Samuel*
}

\section{Introduction}

Should jurists take the notion of an interest as seriously as the notion of a right? This article will argue that while the concept of a right has a powerful rhetorical value that should not be underestimated, it actually is not very helpful as an explanatory device with regard to the reasoning and methods to be found in common law cases. It can certainly express forcefully legal relations that have a strong persona-res property-like structure (quod nostrum est - 'what is ours' - as a sixteenth-century jurist put it), but it is less helpful when the focus of a claim is on, for example, the behaviour of a defendant and where the question is more realistically whether or not the claimant has a remedy given the facts in issue. An interest, while in many ways much less normative and more descriptive than a right, has the ability to be wide-ranging as an analytical tool that functions both within the law and within the facts. It can offer a means for bringing together different areas of law and different models of reasoning.

The purpose of this article is, then, to examine this legal notion that has not received much general attention, at least in recent years, in the UK literature. It will be examined mainly in the context of English law and this examination will be extended into some specific areas of difficulty. But the article will also have a comparative dimension since the concept has received some detailed attention on the continent. ${ }^{1}$ This comparative dimension will, to an extent, be harnessed to support the following thesis to be extracted from the analysis. This thesis is that the notion of an interest is, on the one hand, descriptively and explanatively a far more important concept than the notion of a right but, on the other hand, is, institutionally and conceptually speaking, no less a formal concept than a right. Given this strategic position, an 'interest' could provide an excellent benchmark for assessing legal judgements and legal reasoning.

* Professor of Law, Kent Law School, The University of Kent, Canterbury, Kent, U.K. This article is a much re-orientated, and updated, adaption of a paper published a decade ago: Samuel 2004, at 263. The author would like to thank the anonymous referees for their very helpful criticisms and observations on an earlier version of the manuscript

1 In particular from Professor François Ost: Ost 1990. The present author would like to acknowledge from the outset the great debt owed to this book. 


\section{What Is an Interest?}

If one is to take interests seriously, the first and foremost question is one of definition. What is meant by the term 'interest'? As we shall see, this is by no means an easy question to answer. Yet if an interest is to be taken seriously, it is important that the term is given some substance even if the substance itself turns out to be more flexible or fluid than the strict theorist would desire. This said, the notion of a right is no easier to define as a senior judge in the United Kingdom once observed. ${ }^{2}$ This difficulty of definition has not deterred rights theorists.

\subsection{Rights Thesis}

The late Ronald Dworkin invited judges and jurists to take rights seriously. ${ }^{3}$ Certainly his plea has been heeded in some quarters and there is now a body of jurists specializing in private law who have attracted the name 'rights theorists'. According to Professor Steve Hedley, these theorists: 'regard the key question in obligations cases as the identification of the plaintiff's right, arguing that once this is done, the answer to other questions should fall into place rapidly and uncontroversially'. Such an approach 'minimises reference to policy concerns, which are seen as objectionable."

Like many theories, this rights thesis is challenging. In its purest form it is asserting that legal decision-making should be a matter of inference from an abstract conceptual model that is sufficiently coherent to permit a 'right' to be identified either through its structural relationship with other concepts such as 'duty' and 'liberty' (the Hohfeld model) ${ }^{5}$ or through reference to a set of axiomatic rules or principles (the rule model). ${ }^{6}$ These axioms, according to the rights theorists, are the foundation of legal knowledge and are valid in themselves as law. As Kevin and Susan Gray have put it, axioms 'are simply immune from rational challenge' and to 'knock at an axiom is to want to play a different game'?

However, as a device through which one might understand legal reasoning and decision-making, a highly conceptual rights-based thesis has rather severe limitations. ${ }^{8}$ For a start, it is a theory that simply does not fit all the cases

2 See Lord Oliver in In re KD (a minor) [1988] 1 AC 806, at 825.

3 Dworkin 1977.

4 Hedley 2009, 193, at 196.

5 See e.g. Stevens 2009, 139.

6 Perhaps the founder of this model is Heineccius (1785 edition) where in the preface (at xiii) he says that one must undertake careful research, find clear definitions and axioms; the necessary conclusions will then flow from these clearly defined axioms, which can then be reduced to their principles (Reperies \& hic jurium origines diligenter investigatas, reperies definitiones perquam perspicuas, axiomata clara, \&, quae e definitionibus illis sua sponte fluunt; conclusiones denique necessaria, ad sua quasque principia revocatas). Here in essence is the idea of a conceptual model of axioms, analogous to mathematical constructions (mos geometricus), from which rights (iura) can be deduced. The idea of iura as 'rights' had been clearly expounded by an earlier jurist Hugues Doneau, Commentarii De Jure Civili.

7 Gray and Gray 2003, 204, at 209.

8 As indeed Gray and Gray illustrate with respect to land law decisions: see generally idem. 
in the law reports. Even if one confines oneself to English cases, they still reveal a range of different reasoning models, some of which are not really very amenable to a rights-analysis. ${ }^{9}$ This is not to say that such cases are incapable of being rethought or re-presented in terms of the rights of parties; ${ }^{10}$ but such re-presentation will often shed little light on the reasoning model in play. ${ }^{11}$ Put another way, a rights thesis does not provide a convincing descriptive account of the legal reasoning in the law report texts. ${ }^{12}$ Another limitation is that while the rights thesis has a very solid historical foundation in the civil law, this history turns out to be ambiguous. The kind of highly conceptual and coherent rights thesis that dominated thinking from the usus modernus pandectarum to the Pandectists is now largely seen to be a reasoning myth. Legal thinking during the twentieth century has, even in civil law world, largely been a reaction against what might be called mos geometricus (axiomatic) thinking. ${ }^{13}$ Thus the contemporary private law rights theorists run a serious risk of being seen as little more than a group attempting to recapture and revive a discredited past. Have not jurists like Jean Domat (1625-1696) and Joham Gottlieb Heineccius (1681-1741) said it all before (and perhaps more elegantly)? In short, a rights thesis is unable to explain, except by reference to some pre-existing conceptual model which itself has no epistemological validation other than its own existence, why the right should be recognized as a normative social factor. ${ }^{14}$

9 See generally Samuel 2016.

10 'What is an 'interest'? If the interest is not legally protected, it is, in law, nothing. And if it is, it is a right': this quotation from a civil law writer is quoted by Professor Ost at the outset of his monograph. As he says, it expresses the analytical positivism (dogmatique juridique) of the traditional Belgian private lawyer: Ost 1990, at 9.

11 Samuel 2016.

12 Perhaps illustrated by the following judicial statement: 'In the pragmatic way in which English law has developed, a man's legal rights are in fact those which are protected by a cause of action. It is not in accordance, as I understand it, with the principles of English law to analyse rights as being something separate from the remedy given to the individual': Sir Nicholas Browne-Wilkinson VC in Kingdom of Spain v. Christie, Mason \& Woods Ltd [1986] 1 WLR 1120, at 1129.

13 See e.g. J-L Bergel, Théorie générale du droit (Dalloz, 5th ed., 2012), at 307-309. See also Gordley 2013 , at 275-281. One important critic of the 'axiomatic' approach was the Belgian jurist Chaïm Perelman (1912-1984): on which see Goltzberg 2013.

14 For example, if one asserts that $C$ has a right to $\mathrm{X}$ because $\mathrm{D}$ is under a duty to convey $\mathrm{X}$ to $\mathrm{C}$ this simply begs the question of why $\mathrm{D}$ is under a duty. Such a duty might be justified by reference to, say, a theory of justice but this theory itself begs a question. Why is this theory of justice epistemologically more valid than a theory that legal decisions should be motivated by policy concerns. Ronald Dworkin of course argued that unelected judges ought not to be concerned with policy issues, only with rights. But this just sends one back to the question of why rights are epistemologically valid. Is it because the right represents a social interest that the law is privileging or is it because the right forms part of some conceptual structure that the judge must construct in order to decide a hard case? Perhaps either of these approaches can be grounded in some constitutional and (or) moral theory; but, again, it is not clear why these theories might be epistemologically more valid than some theory grounded in social or policy considerations. See Waddams 2003. 


\subsection{Defining an Interest}

However, one difficulty that has to be faced at the outset is how exactly an interest is to be defined. François Ost makes the point that the term is not only imprecise but is often used interchangeably with the word 'right'. Worse, if one tries to define it by looking at its opposite - what is the opposite of 'interest'? - one equally gets nowhere. ${ }^{15}$ Nevertheless, Peter Cane has suggested that it has two broad meanings. The first is used in the sense of an 'asset':

'When we speak of someone having, for instance, a "property interest", we mean that the person has some sort of claim over or right in some tangible or intangible thing; and when we speak of someone having a "contractual interest" we mean that the person has some claim or right by reason of a contract. In such instances the word "interest" is more or less synonymous with the words "right" or "claim". An interest in this sense relates to (or is "in" or "over") some tangible or intangible thing such as property or contract. A useful general term to describe the subject matter of interests is "assets". ${ }^{16}$

The second is more nebulous:

'On the other hand, we often speak of a person's interests or of the public interest in a broader sense to mean simply objectives or states of affairs which are... or would be, to the person's or the public's advantage: for example, the public interest in the due administration of justice,... or the interest in free competition recognized in the defence of justification in the tort of conspiracy. ${ }^{17}$

And Professor Cane concludes:

"While it is clear that both types of interest may be "legal" in the sense of "recognized and protected by law", interests of the former type are, on the whole, better protected than those of the latter type, at least in the sense that interests of the former type often constitute legal "swords", whereas those of the latter type are often only effective as "shields". ${ }^{18}$

One might add that Tony Weir once suggested that an interest lies midway between 'right' and 'damage'. 'Perhaps,' he continued, 'the relationship can be put this way: all rights, however infringed, involve liability; all legally protected 
interests, relevantly infringed, involve liability; but some damage (e.g. grief), however produced, does not involve liability. ${ }^{19}$

So, what emerges from these observations? There are a number of meanings that attach to the notion of an interest. In real property law and perhaps in the law of contract, the word interest is defined in terms of a legal entitlement, a ius as a civilian might put it, and so, as Professor Cane says, it is more or less interchangeable with the word right. Thus the Law of Property Act 1925 states that the 'only interests or charges in or over land which are capable of subsisting or of being conveyed or created at law are ....; ${ }^{20}$ and that all 'other estates, interests, and charges in or over land take effect as equitable interests'. ${ }^{21}$ One can see here how the expression 'interest' is being employed as a legal term of art.

Second, it is used in an empirical sense to mean a state of affairs that is to the advantage of - or at least of concern to - a person or class of persons. For example, in regulations dealing with misleading marketing, one provision states that before 'granting an injunction the court shall have regard to all the interests involved and in particular the public interest'. ${ }^{22}$ The foundation of an interest in this piece of legislation is very different from its use in real property law; it is a question of fact, which requires the court to examine the concerns of all those likely to be affected by the granting or the withholding of a legal remedy.

Third, it is used as an expression that lies midway between a right and a situation where someone has suffered what might loosely be described as an identifiable disadvantage, such as the suffering of harm. The term interest is used here to categorize in an empirical sense the type of harm suffered. And so one might talk of a person suffering an invasion of her 'financial interest' or 'mental health interest' as opposed, say, to suffering physical damage to her 'property interest' or 'bodily interest'. What is useful about this approach is that it can help quantify empirically different types of harm, which in turn will facilitate the legal reaction to such types of harm.

It is evidently not easy to induce out of these three meanings (and they may not be exclusive) any single definition of the term interest. For the purposes of this present investigation, however, the expression will for the most part (but not exclusively) be employed primarily in the second sense outlined above. That is to say, it will be defined as meaning some state of affairs in which a person or class of persons - or sometimes a non-personified 'thing' (res) such as the environment or justice - has an advantage or a concern. This definition may on occasions draw into the meaning the third possibility outlined above; that is to say it might treat this state of affairs described in terms of an interest as a halfway house between this factual situation (empirical) and a right (normative).

19 Weir 1967, at 3

20 Section $1(2)$.

21 Section $1(3)$.

22 Business Protection from Misleading Marketing Regulations 2008 reg 18(2). 


\subsection{Advantages Attaching to the Notion of an Interest}

Whatever the difficulties, there are nevertheless quite a few reasons why an 'interest' deserves a more detailed analysis. It is a notion that by its very nature is central to legal analysis since it is one that, like the legal subject (persona) or the legal object (res), exists at one and the same time in both the legal world and the world of social reality. It is, in other words, a truly mediating concept between fact and law. Second, it is a notion that goes back to Roman law and thus is a legal concept that should attract the attention both of the legal theorist specializing in epistemology and of the comparative lawyer. ${ }^{23}$ Equally, and this is a third reason, it is a concept that connects with a 'right'. An interest often appears, as we have mentioned, to be a kind of halfway house between a right and a remedy. ${ }^{24}$ The notion of an interest is, accordingly, a useful starting point for examining a range of other legal concepts. Fourth, an interest is a notion that connects with the persona (legal subject) as an individual: to determine an interest, is to determine a legal subject and his, her or its expectations. ${ }^{25} \mathrm{An}$ interest, then, is a legal concept that can play a central role in legal thought and legal reasoning; it is a 'passport' to all areas of the law. ${ }^{26}$ Fifth, in having its basic roots in the world of fact rather than in the normative abstraction of law, it is a concept that would appear to lie beyond the rule. It is a notion that, itself, suggests that legal knowledge is not exclusively rule-based.

Indeed, this factual dimension to the notion of an interest allows it to be used as the basis of an 'actional' scheme of intelligibility, ${ }^{27}$ that is to say a scheme that 'reads' social reality as consisting of individual actors as the primary units. In economics it is a matter of self-interested actor. ${ }^{28}$ Because such an actor also has a role in the legal plan, the notion of an interest can act as a link between law and another discipline such as economics. ${ }^{29}$ Having said this, an interest can equally be used to help define a fragmented group that is not solid enough to be endowed with its own legal personality. ${ }^{30}$ For example, one can talk of the interests of consumers or of a local community. Finally, therefore, the notion of an interest is a key means by which one can understand legal reasoning. It bridges the gap not just between legal substance and legal method, but equally between judgment and solution; it is the means by which one can have access to socio-legal ideas that lie behind the more formal elements of legal knowledge, that is to say behind rules and legal rights. ${ }^{31}$ It is, in brief, a key to legal knowledge.

Zimmermann 1996, at 35-38, 826-827.

See e.g. Chief Constable of Kent v. V [1983] 1 QB 34.

Jolowicz 1983.

Ost 1990, at 10-11.

This scheme is discussed in Samuel 2014, at 88-89.

Leroux and Marciano 1998, at 15-18.

See e.g. ParkingEye Ltd v. Beavis [2015] UKSC 67.

See Jolowicz 1983, at 222.

An excellent recent example is to be found in Lord Sumption's discussion of the scope of the ex turpi causa rule: 'In my opinion the question what constitutes 'turpitude' for the purpose of the defence depends on the legal character of the acts relied on. It means criminal acts, and what I have called quasi-criminal acts. This is because only acts in these categories engage the public 
Now the 'actional' scheme strongly suggests that interests tend to attach to the person: that is to say, that a person acts in his or her own best interests. ${ }^{32}$ This in turn might imply that the only way these interests could be modelled, given their number and variety, is through an alphabetical list. Yet the empirical orientation of an interest in fact permits it to be modelled through an institutional analysis. That is to say an interest lends itself to a schematization first used by Gaius and then by Justinian in their Institutes and later adopted as the structural foundation for all the modern codes. ${ }^{33}$ Interest can be seen as a concept that attaches on occasions as much to 'things' (res) and to 'actions' (actiones) as to the persona. Thus one can talk, as has been seen, of having a legal interest in land or of an interest requirement that attaches to a particular kind of legal remedy (for example, judicial review).

Of course, such interests can equally be seen as attaching to the person and indeed all interests, if regarded as 'things', can be reduced to a subject-object relationship. However, the suggestion here is that interests can be seen not just as attaching to persons. They have an orientation as well, which means that from an institutional position (persons, things and actions) there are interests, which are orientated, or perhaps one might say as much attached to, things and to actions as they are to persons. The advantage of this institutional perspective is that it allows for an analysis of an interest from more of a 'three dimensional' model than is the case when interest is seen primarily from the position of the legal subject. It provides a perspective through which very different kinds of interest, or interest relationships, can emerge and as a result the institutional system is able to provide a useful conceptual starting point. Such a model functions in truth more as a halfway house between social reality and law and thus takes on the status of an object of legal science. Taken together, then, the notion of an interest and the institutional system provide a - perhaps the - model by which social fact, as 'constructed' by the institutional system itself (persons, things and legal actions), connects with law, also organized, at least on the continent, by the institutional plan. ${ }^{34}$ Social

interest which is the foundation of the illegality defence. Torts (other than those of which dishonesty is an essential element), breaches of contract, statutory and other civil wrongs, offend against interests which are essentially private, not public. There is no reason in such a case for the law to withhold its ordinary remedies. The public interest is sufficiently served by the availability of a system of corrective justice to regulate their consequences as between the parties affected': Les Laboratoires Servier v. Apotex Inc [2014] UKSC 55, at para. 28 (emphasis added).

32 See on this aspect von Jhering 1913, where he defines interest in terms of pleasure and pain (pp. 26-27). Later he says: 'Nature herself has shown man the way he must follow in order to gain another for his purposes: it is that of connecting one's own purpose with the other man's interest. Upon this principle rests all our human life: the State, society, commerce and intercourse' (p. 28). Note also Rosco Pound's preference in teaching jurisprudence 'to build on Jhering's idea of interests, defining them as claims or wants or desires (or, I like to say, expectations) which men assert de facto, ...': Pound 1959, at 15. On Jhering, see Gordley 2013, at 287-292.

33 On the institutional system and its development, see Stein 1983, at 151-163; Stein 1988, at 73-82. See also Samuel 1994, at 171-190.

34 See further, Samuel 1997, 448. Roman law used this plan only for teaching purposes and thus the great practitioner work, the Digest, does not employ the scheme at all. The first jurist to rethink the Digest in terms of the institutional plan was Hugues Doneau (1527-1591). His 
'reality', in other words, starts its connection with legal discourse through the notion of an interest; and this connection is completed through the relationship between an interest and the institutional plan. ${ }^{35}$

\section{Interests Attaching to the Persona}

The Digest of Roman law begins its analysis of law with the ius personarum on the ground that law is made for the sake of mankind. ${ }^{36}$ Given that the Digest also says that law is about the protection of interests (utilitates), ${ }^{37}$ the persona equally acts as a good starting point for the examination of the notion of an interest. Indeed one might say that the law is made for the protection of personal interests with the result that if a person goes missing his or her interests remain in existence in need of protection by another persona. ${ }^{38}$

\subsection{Personality and Best Interests}

These interests are of course wide-ranging and varied and if one wished to analyse all the various types and classes, one would be in effect studying the whole mass of laws themselves. ${ }^{39}$ However, the general point to be made about the notion of an interest in relation to the institution of the persona is that it can act as a vehicle for giving expression to the idea of personality itself. It can do this in two main ways. First, the notion of an interest can be used to give form to intangible 'things' that attach intimately to the conception of a person..$^{40}$ Perhaps the

Comementarii de jure civili runs to 28 volumes and was probably unfinished at the time of his death. Doneau also, as has been mentioned, rethought the Digest from the viewpoint of a subjective 'right' ('what is ours' and 'what is owed to us'). A much more precise restatement of the civil (Roman) law, although not actually along institutional lines, was produced by the French jurist Jean Domat (1625-1696): Les loix civiles dans leur ordre naturel (first edition 1689). This was important because it built upon the idea that Roman law could be restated in terms of fundamental principles (Heineccius' axiomata). However, Heineccius' work, though much, much shorter than Doneau's Commentarii, nevertheless followed the old order of the Digest. Domat rearranged the 'axioms' into a two-part structure consisting of engagements and succession (des successions), although in the opening general part he sees law consisting of general rules (and their interpretation), persons and things. Domat is, then, probably the true 'father' of the modern civil codes. Contemporary rights theorists in the common law world are really attempting to read cases in much the same way as Doneau, Domat and Heineccius read the Digest; they are hoping to extract from them (or those that they approve) a conceptual model (axiomata).

35 This is not to argue that the common law is fully amenable to the civilian institutional analysis. In many ways it is not. But the common law does share the basic institutions of person (legal subject), thing (legal object) and remedy (legal action) with the civilian systems. Cf. Samuel 2013, at 104-108.

36 D.1.5.2.

37 D.1.1.1.2.

38 Code civil Art. 117

39 Which is in effect what Pound does and this is one reason why his Jurisprudence covers five volumes.

40 'Individual interests are claims or demands or desires involved in and looked at from the standpoint of the individual life immediately as such - asserted in title of the individual life': Pound 
two best examples to be found in French law are dignity and privacy; these are not part of a person's patrimony and so do not fall into the category of the law of property. They are very much part of the law of persons. ${ }^{41}$ These interests of personality do not, accordingly, attract a monetary value as such and they cannot (in theory) be traded..$^{42}$ Now the fact that they are given specific protection in the Code civil obviously has the effect of endowing privacy and dignity with the status of rights rather than just interests. ${ }^{43}$ But as Professor Ost points out, despite this status, there are still hesitations in as much as the code is by no means clear as to how these rights are to be protected. ${ }^{44}$ They are not like obligation or property rights that are given direct protection in the law of actions; ${ }^{45}$ instead they are more like 'interests', which can be treated as 'patrimonial' if they are invaded. ${ }^{46}$ This 'patrimonial interest' aspect is well brought out by an English case concerning an elderly Norwegian man who suffered a severe stroke while in England. ${ }^{47}$ A dispute arose between the family of the man and the man's close friend: the family (defendants) wanted the man returned to Norway for care while the friend (plaintiff) wanted the man to be treated in an English private nursing home. Given the fact that the man himself was unable to communicate, the whole reasoning process had to shift from 'rights' to 'interests'. What was in the 'best interests' of the man himself? Did each of the parties have a 'legitimate interest' in the legal dispute? With respect to the second question, Millet LJ was of the view that 'unless the court is willing to entertain proceedings brought by the parties who claim the responsibility for looking after the patient it will often not be possible to bring proceedings at all.' And this would be unfortunate since 'the parties are likely to resort to self-help. 48 This second question is essentially one where the interest attaches to the actio rather than the persona, but while the case is very much a law of persons problem, the inability of the right-holder himself to assert his rights in court creates structural problems. As Professor Ost recognizes with regard to the civil law tradition, the notion of a right is extremely ambiguous as a practical reasoning device when taken out of its property context. ${ }^{49}$ It simply does not function properly when applied to 'rights' of personality since the idea of being the master of one's own body does not always find expression in legal

1959 at 23.

41 Code civil, Arts. 9 (privacy), 16 (dignity).

42 Ost 1990, at 122. Note, however, that if these interests are invaded, damages are awarded often via Code civil, Art. 1382 and to this extent they thus appear as patrimonial interests. Note, for example, in English law the Human Organs Transplants Act 1989 s 1.

43 This idea of personality rights goes back to Doneau Commentarii, Book 1, Chapter 1, para. 3. Doneau does not list privacy but he does mention dignity (existimatio).

44 Ost 1990, at 117-124.

45 Thus, in the civil law, property rights are protected by actions in rem and obligational rights by actions in personam.

46 Cf. Protection of Harassment Act 1997 s 3.

47 In re S (Hospital Patient: Court's Jurisdiction) [1995] 3 WLR 78.

48 At 92 .

49 Ost 1990, at 122. 
structures. ${ }^{50}$ What one is really talking about, says Ost, is the protection, through a variety of means, of a 'simple interest'. This may seem a rather extraordinary conclusion given the importance, in the scale of legal values, of the human body. Human rights are fundamental ${ }^{51}$ and one of the most fundamental of these human personality rights is the right to life. Yet even here the English case law indicates that institutionally this can often be handled only by recourse to the notion of an interest. ${ }^{52}$

In the Tony Bland case the courts were asked to rule, in an action for a declaration, if a hospital could discontinue a life support programme for a young man who, as a result of the dreadful Hillsborough tragedy, was rendered permanently unconscious with, according to medical opinion, no chance of recovery. ${ }^{53}$ In short, could the hospital allow the young man to die by withdrawing the feeding necessary to keep him functioning in his vegetative state? One might have thought that the starting point for this legal action would have been the right to life that attaches to the human persona, yet this was not the concept that formed the basis of the reasoning and the decision. ${ }^{54}$ Instead the judges focused on the notion of an interest and asked what would be in the 'best interests' of Tony Bland. The reason for this shift of emphasis becomes evident when one considers the final decision reached in the case: the House of Lords came to the conclusion that it would be in the best interests of Bland if he were to be allowed to die. ${ }^{55}$ Had the judges approached this case in terms of rights, it would have been extremely difficult to conclude that Bland should be allowed to die since this would have appeared to contravene his fundamental human right to life. ${ }^{56}$ The notion of a right would have emphasized the persona. However, in replacing 'right' with 'interest' the lawyers were able to effect a shift from the subjective to the objective. ${ }^{57}$ Tony Bland became, to use the expression of Millet LJ in the case discussed earlier, analogous to a 'sack of potatoes' whose 'interests' were to be considered detached from the persona itself. ${ }^{58}$

50 The Romans said that one is not owner of one's own limbs and as a result a freeman negligently injured did not at first have a claim for damage to his body: D.9.2.13pr. However, such an important interest was not in the end left unprotected: D.9.1.3.

51 Human Rights Act 1998.

52 What the notion of an interest does in this situation is not so much to give effect to some pre-existing claim or demand or expectation existing empirically (although these must have some basis in fact). It gives an alternative and objective view of the conceptual (institutional) structure since the subjective view is eclipsed by the unconsciousness of the main right-holder.

53 Airedale NHS Trust v. Bland [1993] AC 789.

54 See now on the relationship between the right to life and the interest of the patient: NHS Trust A v. M [2001] 2 WLR 942.

55 One might note that the decision also served the 'best interest' of the hospital trust given the financial cost of keeping Bland alive. One could certainly talk in terms of Bland's 'right to die' but it would not really have been feasible (or tasteful) to talk in terms of the hospital's 'rights' with regard to this patient.

56 Cf. Ward LJ in In re A (Children) (Conjoined Twins: Surgical Separation) [2001] 2 WLR 480 at 537.

57 See also Mental Capacity Act 2005 s 4.

58 In re S (Hospital Patient: Court's Jurisdiction) [1995] 3 WLR 78. at 94. 


\subsection{Interests Rather Than Rights}

A second way in which the notion of an interest can give expression to the idea of personality is through the specific recognition of an interest, or set of interests, existing independently of the legal status of the subject him or herself. Thus in the area of family law children are deemed to have their own interests, which are to be treated independently from, say, the interests of the parents ${ }^{59}$; and since Roman times these interests come into existence before the actual legal personality of the child itself. ${ }^{60}$ The concept of an interest and the notion of a persona are therefore not interdependent in quite the same way as rights and legal personality. This décalage allows the notion of an interest to be extended beyond human legal subjects in a way that would be controversial if it were rights rather than interests that were in issue. For example, legislation can talk about the interests of animals without raising the kind of philosophical controversy that would inevitably result had the text talked in terms of rights. ${ }^{61}$

This ability to extend beyond the existence of the persona is particularly useful when it comes to interests that attach more to groups of human beings rather than just to the individual. These interests are often, to begin with at least, rather diffuse and may well remain legally unrecognized until given shape by attachment to some, perhaps equally diffuse, legal subject. ${ }^{62}$ Legal 'subject' in this context must be understood in two rather different ways. The first way is simply as a category and thus the interest in issue is one that attaches to a category of persons; one talks here of 'interest groups'. The category of 'interest groups' is full of examples: one recent text lists various interests groups as including teachers, employers of teachers, providers of teacher training and so on. ${ }^{63}$ Another Act talks of the 'interests of local government, industry, agriculture and small businesses, ${ }^{\prime 64}$ while yet another piece of legislation mentions 'persons able to represent the interests of particular kinds of litigants (for example, businesses or employees). ${ }^{65}$ It would be a gross exaggeration to say that the existence of these various interests has the effect of creating new legal subjects. Accordingly, the capacity of, say, a local authority to obtain an injunction in the interests of the local inhabitants does not as such turn the local community into a legal person. ${ }^{66}$ Nevertheless, local government, agriculture, small businesses, teachers, employers and employees are interest groups that often find it valuable to create specific legal persons or associations, which are to act as a focal point for the representation of their interests. Indeed, even if such groups lack any kind of legal personality, procedural rules may nevertheless give indirect recognition. ${ }^{67}$ Sometimes these associations

60 D.1.5.7.

61 Animals (Scientific Procedures) Act 1986 s 5(3)(c).

62 See generally Jolowicz 1983.

63 Teaching and Higher Education Act 1998 s 1(6).

64 Pollution Prevention and Control Act 1999 s 2(4)(c).

65 Civil Procedure Act 1997 s 6(2)(f).

66 Local Government Act 1972 s 222.

67 See further Samuel 2016, at 120-121. 
become so prominent that they change the symmetry of the law itself. The creation of trade unions and employers associations had the ultimate effect of creating a new category of law: labour law is now a subject independent of the law of obligations. ${ }^{68}$

\section{Interests Attaching to the Res}

Interests can also attach to - or be more orientated towards - a res. In property law, as we have seen, the term 'interest' is used to describe a person's specific legal relationship with an object of property; lawyers in the common law world talk of a person having a legal interest in a piece of property, a fund or even a chattel. Here the term is being used not in its descriptive sense, but, as was mentioned in the introduction, in the sense that is often much closer to that of a legal 'right' in the property. As Peter Cain put it, the interest can be more or less defined as an 'asset'.

\subsection{Legal Interests in Property}

The term interest is used in its most formal property sense in land law. The 'rights' referred to in Section 1(2) of the Law of property Act 1925 are not referred to as 'estates' in land - these are dealt with by Section 1(1) - but 'interests' or 'charges'. These 'interests' can be analysed, as with any legal 'right', by reference to positive rules of land law and in this context they lose, if not all, certainly part of their descriptive character. In other words, the notion of an interest can in this context be defined, at the outset, as a normative concept. However, on closer examination the position turns out to be more complex since an 'interest' in another's property can include a possessory relationship and possession is a relation said to have its root more in fact than in law. ${ }^{69}$ Thus if someone finds an item of property in the street and takes it home it can be asserted that the finder has taken 'possession' of it. Moreover, the finder could even assert that he has an 'interest' in the thing to the extent that if it were to be stolen from his house he could go some way in claiming a relationship with the item were the police to recover it. ${ }^{70}$ Of course the legal analysis cannot, and does not, stop at this descriptive stage; it has to go on to decide whether the finder has, as a result of his former possessory relationship with the thing, an entitlement to it. Should the original owner arrive at the police station to assert his legal title this would no doubt destroy any normative enti-

In this respect the Pound thesis of pre-existing interests ultimately recognized by the law and given expression in legal rights or powers has much to commend it. There is no doubt that these interests can be said, in some form, to pre-exist empirically. All the same, the role of the institutional system must not be underestimated either; the conceptual formation of new interest groups goes far in itself in giving substantive content to the interests in as much as the law creates an institutional model in which these interests seemingly find expression. One is no longer focusing on the sociological facts as the foundation of the interest but the institutional model and as such the law will have as much input into the model as any social fact.

69 D.4.6.19.

70 Lawson and Rudden 2002, at 64-65. 
tlement - or 'right' - that the finder might have had. But what if no owner could be traced? It may be that the finder's possessory 'interest' would entitle him to the thing over and above any other citizen (save of course the original owner). ${ }^{71}$ In other words he would have a right to possession and this turns possession - and the interest that attaches to it - into a normative concept. ${ }^{72}$

The switch from the descriptive to the normative is usually effected through the legal actio - the finder will bring an action against the person in actual possession - and this will force a court into deciding who has the best right to possession. ${ }^{73}$ One might accordingly see the problem as one of an interest attaching not so much to the thing but to the remedy. This analysis is of particular importance when it comes to equitable remedies and so, for example, a person who has contracted to buy land will be able to claim specific performance of the contract should the seller refuse to perform. ${ }^{74}$ A contract right in effect becomes a right to the thing itself and thus a kind of property right. However, not all equitable remedies that are concerned with property actually attach to the res itself; some are personal and therefore are not equivalent to interests in property. For example, if a householder obtains an injunction against a neighbour ordering the latter not to play loud music in the middle of the night, this equitable remedy will be in personam (against the neighbour in person) and will not attach to the neighbour's land (in rem).

\subsection{Property Interest Conflicting with Other Interests}

Nevertheless, an injunction can create what might be called a weaker interest with respect to property. In Wandsworth $L B C v$. $A^{75}$ a local authority obtained an injunction, on the grounds of her abusive behaviour, against a parent excluding her from entering the school where her child was being educated. On appeal the Court of Appeal discharged the injunction because the local authority had not given the parent an opportunity to be heard before excluding her from the school. Buxton LJ, delivering the judgment of the Court, said that 'the local authority has an obligation in public law to educate their children' while the 'parent has a correlative interest in seeing the duties of the authority properly performed.' This does not give the parent a 'right to interfere with how the professional educators undertake their work, but it does give him an interest in being informed about their work, with the possibility of formal representations about it.' This makes the parent 'a more significant figure' than 'a mere visiting tradesman.' The court was of the opinion that such a tradesman could be excluded from a school 'without any inhibition in public law' but a parent could not. ${ }^{76}$

72 Lawson and Rudden 2002, at 65. The expression ius possessionis is even to be found in the Roman sources: D.41.2.44pr.

73 See e.g. Waverley BC v. Fletcher [1996] QB 334.

74 Lawson and Rudden 2002, at 59, 84-85.

75 [2000] 1 WLR 1246.

76 At 1253. 
One might note here that the key concept is the 'interest'. The parent, as the court stressed, does not have any rights as such, but she does have an interest that puts her in a different class than other visitors. Arguably this interest is descriptive in as much as it arises simply out of the fact that the child is attending the school, but its quasi-normative dimension is equally relevant. This quasi-normativity does not, of course, result from any relationship with the school property and thus is a legal relationship, which is completely independent from the local authority's proprietary (ownership) relationship with the land. However, it does nevertheless raise an interesting question about the extent to which public law (imperium) can impinge upon private law dominium. To what extent does 'interest' act as a means of turning a central area of private law, that is to say the law of property, into a form of 'quasi-public' law? The point is an important one because 'interest' could, in this situation, end up as the foundation for the only viable means of establishing a balance between the exercise of the private power of dominium and the constitutional and administrative control of such power.

The problem has been investigated by two leading property lawyers who indicate, clearly, how, without proper consideration being given to principles of public law and their relationship with principles of private law, the exercise of dominium can lead to constitutional injustice. ${ }^{77}$ The transfer of a public monopoly into the private arena, which in legal terms means a shift from imperium to dominium, has dramatic effects at the level of legal concepts since the transfer puts the corporation beyond the reach of judicial review. How are the interests of citizens to be equally translated? Kevin and Susan Gray give the example of the privatized water company able to acquire land by compulsory purchase (in the 'public interest'), which in turn allows the private company to further its own commercial interest (private profit) at the expense of those individuals forced to give up their homes at below commercial value prices and at much inconvenience. ${ }^{78}$ The so-called public and the commercial interest are advanced at the expense of the individual interest. The reverse side of this argument can be seen when private individuals, employed to run private companies operating a public service like the railway, are given huge bonuses. Here the private interest profit is justified because it will act as 'an incentive to do well' thus, presumably, enhancing the public interest..$^{79}$ The point to be made here is that the notion of an interest, rather than a right, more readily highlights the problem in issue.

\section{Interests Attaching to the Actio}

The notion of an interest can attach - or again be orientated towards - not just to the person and to a thing but also to the legal remedy, which gives it an important role in procedural law. Again the point must be stressed that such remedy- 
orientated interests can of course be seen as interests equally attaching to a person. What is being argued is that it is more helpful from an analytical, and legal reasoning, point of view to regard them as attaching to the remedy rather than to the person.

\subsection{Interest and Procedure}

This procedural point is not new and has in fact a history stretching back to the Roman actio popularis. These popular actions were theoretically available to any member of the public and could be brought, for example, against an owner of a building adjacent to a highway from which something had been thrown or poured causing injury to highway users. ${ }^{80}$ Being public penal actions they were designed to protect the public interest (utilitas publica) in using the streets without danger, ${ }^{81}$ but those with a particular interest (interest) in bringing the action would be given preference to sue. ${ }^{82}$

This idea of restricting legal actions only to those with a legitimate interest in the proceedings has been developed into a general principle within the civil law tradition: pas d'intérêt, pas d'action. ${ }^{83}$ In other words a plaintiff who wishes to bring, or defend, an action in the civil courts must either have a legitimate interest in the success or failure of the proceedings or be a person given power by statute to vindicate or defend a specified interest. ${ }^{84}$ Thus it was once the situation in French law that an unmarried partner who had lived with a fatally injured victim of a tort could not sue the tortfeasor because the partner lacked a legitimate interest in the actio. ${ }^{85}$ This interpretation has now been abandoned, but what is interesting about the legitimate interest requirement is that it can act as the basis for both a narrow and a wide view of liability. It can restrict the number of plaintiffs able to sue when it attaches to the persona, but of course can increase the types of damage (that is to say interests) legitimately protected. ${ }^{86}$

Probably a similar rule exists in English law in respect of civil proceedings, ${ }^{87}$ although of course concepts such as 'duty of care', or the requirement of damage, often fulfil the same role and thus make superfluous any legitimate interest provision. ${ }^{88}$ However, statute now confers on a number of public officers or bodies the

83 Roland and Boyer 1986, at 724-733.

84 French Code de procédure civile Art. 31.

85 Cadiet et al. 2013, at 346-347. One might note how, once again, this legal situation was a good example of how interest was as much dependent on the institutional system as on empirical fact. As a matter of strict social fact, the interests of a married and unmarried couple are identical; the difference is simply one of the existence and non-existence of the legal relationship of marriage. The absence of legal protection to the unmarried partner was being determined by an 'interest' whose substance was being defined entirely by reference to the law.

86 Cadiet et al. 2013, at 347-348.

87 Lall v. Lall [1965] 3 All ER 330; The Nordglimt [1988] QB 183, 199-200.

88 See e.g. Rothwell v. Chemical \& Insulating Co [2008] 1 AC 281. 
power to seek certain remedies on behalf of specified interests ${ }^{89}$ and this statutory power has been extended to the Consumers Association in respect of unfair terms in consumer contracts. ${ }^{90}$ Yet whatever the position with regard to English private law and legal remedies, in public law the interest rule is quite specific. A person wishing to bring an action for judicial review must have a 'sufficient interest' in the matter. ${ }^{91}$ In other words, in public law, the law of actions is kept separate from substantive law exclusively through the use of the notion of an interest. An individual is entitled to commence a judicial review action only if he has a 'sufficient interest' and this must logically be separate from the substantial public law 'right' that will be in issue in the judicial review claim itself. ${ }^{92}$

\subsection{Procedural Interests and Substantive Rights}

Care must thus be taken, if the distinction between right and interest is to have any conceptual meaning, to keep 'interest' separate from 'right'. If care is not taken here, the law of actions issue will soon become at least partly merged with the substantive law question. And the result will be that the question whether or not a private person can bring a legal action will become very close to depending upon the actual substance of the claim itself..$^{93}$ The requirement of 'sufficient interest' can, accordingly, easily transform itself into a kind of public law preliminary question of law, or a public law striking out action, either raising 'interest' effectively to the status of 'right' or reducing 'right' to little more than an interest. ${ }^{94}$ Such a transformation would be an error in as much as the purpose of the requirement is the exclusion of potential claimants on the ground that there is an insufficient connection between persona and actio. The locus standi question is not really something that goes to the lawfulness of an administrative decision. Such a requirement is no doubt necessary with regard to certain kinds of remedies where individual damage is not a precondition since it would probably introduce into law an unacceptable insecurity if everyone had the right to challenge in court an unlawful act of another. ${ }^{95}$ Nevertheless, the notion of sufficient interest might go well beyond the descriptive in as much as it can raise a question as to whether a particular interest group ought to be regarded, in effect, as a legal subject. This can become acutely conceptual in that it raises on occasions the question of whether a group of persons add up to more than the sum of the individuals.

Take for example a government minister who makes an unlawful decision that has consequences for the environment but does not actually invade the individual

89 See e.g. Financial Services and Markets Act 2000 ss 380-381; Enterprise Act 2002 s 213.

90 See now Consumer Rights Act 2015 Schedule 3 s 8(1)(k).

91 Senior Courts Act 1981 s 31(3).

92 Ibid.

93 See e.g. I.R.C. v. National Federation of Self-Employed and Small Businesses Ltd [1982] AC 617.

94 In truth administrative lawyers talk in terms of 'legitimate expectations' rather than 'rights'. However, this expression, 'legitimate expectation', is surely closer to the notion of an interest than a right.

$95 R v$. Secretary of State for the Environment, Exp Rose Theatre Trust Co [1990] 1 QB 504, at 519 per Schiemann J. 
interest of any single individual. According to one judge the mere assertion of an interest does not give one an interest. Thus the 'fact that some thousands of people join together and assert that they have an interest does not create an interest if the individuals did not have an interest'. ${ }^{96}$ Perhaps not, but the position is more complex than the judge seems to suggest. A wine distributor sells as litre bottles of wine bottles that in fact contain only 98 centilitres and secures for itself a huge profit. No single consumer suffers any measurable loss as far as the law is concerned, yet the buyers as a class have been deprived of a large amount of money. The same applies with respect to the environment. It may be that an unlawful decision by a minister, or an unlawful act by a commercial organization, causes no measurable invasion of any individual interest, but this does not mean that a class of persons will be unaffected. If the commercial organization profits from its unlawful act it will, without doubt, have advanced its commercial interest. Is one forced to say that this advance is cost-free since no individual interest is affected? What if a group of drugs companies launch onto the market at the same time, and at great profit to themselves, a drug that is dangerous? Does one have to wait for an individual consumer to suffer before one can say that consumers as a class has had its interest threatened? ${ }^{97}$

\section{Abuse of a Right and Legitimate Interest}

None of what has already been said should be taken as asserting that there are never occasions when the notion of an interest, at the level of the remedy, should not be used to outflank a right. Indeed, it has already been noted that in civil law systems a right holder is entitled to sue only if there is a legitimate interest in the proceedings. Often, by definition, if the right-holder is seeking to vindicate his right, this in itself will provide the interest. However, there are occasions when it could be said that a right-holder has no interest in enforcing his rights.

\subsection{Are Rights Absolute?}

The French Code civil lays down in one of its most famous articles (Article 544) that 'ownership is the right to enjoy and to dispose of things in the most absolute manner.' But the Cour de cassation has stated that this 'absolute right' is subject to the limitation that it can be exercised only in satisfaction of a 'serious and legitimate interest. ${ }^{98}$ Thus a landowner who grew 2-metre high ferns on her land with the sole purpose blocking out the light of her neighbour was held to have

96 Ibid., at 520.

97 Note also that there is a causal point that can arise in these kinds of cases. If a consumer is injured by a drug launched onto the market by several independent drug companies but it is not possible to locate the actual company responsible for supplying the dangerous drug, does this mean that the consumer interest and the victim's private interest must suffer at no cost to the general commercial interest? Cf. Fairchild v. Glenhaven Funeral Services Ltd [2003] 1 AC 32. 
committed a tort and declared liable in damages to her neighbour. ${ }^{99}$ The basis of this action for damages was not the interference with the neighbour's property or contractual right, for the neighbour did not have as such a right to light. It was the malicious behaviour of the landowner that deprived the exercise of the right to grow plants on one's land of its legitimate interest. In an earlier case the French Supreme Court had made a similar ruling with respect to a landowner who had erected 16-metre towers on his land topped with spikes with the deliberate intention of interfering with his neighbour's ballooning activities. These towers went way beyond anything needed to protect the landowner's 'legitimate interests. ${ }^{100}$ The importance of the two cases is that they established the doctrine of abuse of rights based on the relationship between subjective 'malice' and objective 'interest'. ${ }^{101}$

The theory of abuse of rights did not confine itself to the law of property but expanded into other areas of private law. ${ }^{102}$ Again these developments involved the notion of an interest. In the area of family law, for example, abuse of family property rights by a spouse might be curtailed where the interest of the family was threatened. ${ }^{103}$ And in contract the theory, along with good faith, ${ }^{104}$ helped develop the idea that each party to a contract had to consider not just their own commercial interests but also the legitimate interests of the other contracting party. It is a question of the 'common interest'. ${ }^{105}$ In company law the rights and interests of shareholders might well take second place to the interests of the company as a whole (at least in the civilian tradition). ${ }^{106}$

What is so important about this civilian development is that while it is clearly something that focuses on the concept of a right, the actual vehicle by which the theory of abuse of right has been put into effect is the notion of an interest. As Professor Ost has stated, its positive influence is incontestable. Sometimes an interest acts as a means of curbing an excess of selfish individualism such as where the group interest takes precedence over that of the individual. Sometimes it ensures the stability of contract by stressing the common interest of the two or more parties. ${ }^{107}$ These developments have not, it must be said, occurred without severe criticism from those who considered that the doctrine of abuse of rights amounted to the undermining of the absolute nature of a right and depriving it of its conceptual force. As Ost says, the 'consideration payable for the satisfaction of interests is the correlative weakening of subjective rights. ${ }^{\text {'08 }}$

99 Ibid.

100 Cass.req.3.8.1915; D.1917.I.79.

101 Ost 1990, at 143.

102 Bergel 2012, at 291-292.

103 Ibid., at 292.

104 Rampelberg 2005, at 54-56.

105 Rochfeld 2011, at 431.

106 Ost 1990, at 86.

107 Ibid., at 152-153.

108 Ibid., at 167. 


\subsection{Liberty, Expectations and Interests}

This ability of an interest to weaken the notion of a 'right' goes some way in explaining why the notion of a subjective right has never had the same force in English law as it has had on the continent. ${ }^{109}$ English law has thought more in terms of liberty rather than rights; and liberty, as Ost explains, is at the basis of the notion of an interest. ${ }^{110}$ This lack of rights-thinking in English law has resulted equally in a lack of any formal theories of abuse of rights. Problems that would be treated as an abuse of a right in civil law tend, in England, to be solved on the basis of the law of actions (remedies), which in turn look to behaviour and reasonableness. A reasonable level of noise may become an unreasonable interference with a property interest if the noise is the result of a malicious motive. ${ }^{111}$ In public law, equally, the emphasis is not on the rights of citizens, but on what they might reasonably expect from a public service. ${ }^{112}$ But such a 'legitimate expectation' can nevertheless function more or less as a 'legitimate interest' with the result that a public body will not be able to enforce any of their 'private' law property or contract rights if it lacks a proper interest in its exercise. ${ }^{113}$ These abuse cases do not in strict theory draw their normative force as such from the motive of the defendant since motive has been said to be irrelevant when it comes to the exercise of a property right. ${ }^{114}$ The normative force in these cases comes from the existence of a cause of action or a remedy like judicial review. This creates a rather complex picture because motive gets relegated to a seemingly more indirect role. A contractor may not be granted his full right to damages if the 'expectation interest' that he is, perhaps unreasonably (in the eyes of the judges) asserting, is according to the court not the actual interest in play. ${ }^{115}$

The question is whether one can go further and use the notion of an interest as a positive means of remedial intervention. A person exercises a legitimate liberty deliberately to interfere with a legitimate interest of another: will a remedy be available to the person whose legitimate interest is invaded? This question takes us to the heart of the relationship between rights, remedies and interests, for if a court is prepared to grant a remedy it would immediately seem to flow, logically, that the interest is being transformed into a protected right. ${ }^{116}$ It is this bootstraps circularity that gives legal reasoning its force as an informal source of law. In particular the interest approach has been used to support the granting of injunctions. On one occasion a defendant was restrained from doing an act, not itself wrongful, simply because it interfered with the commercial interest of the plaintiff without furthering, according to the court, any interest on the part of the

109 Samuel 1987, at 264.

110 Ost 1990, 185-186.

111 Christie v. Davey [1893] 1 Ch. 316; Hollywood Silver Fox Farm v. Emmett [1936] 2 KB 468.

112 Council of Civil Service Unions v. Minister for the Civil Service [1985] AC 374.

113 Wheeler v. Leicester CC [1985] AC 1054.

114 Bradford Corporation v. Pickles [1895] AC 587.

115 Ruxley Electronics Ltd v. Forsyth [1996] 1 AC 344.

116 Cf Hubbard v. Pitt [1976] QB 142. 
defendant. ${ }^{117}$ On another occasion the Court of Appeal was prepared to restrain a defendant from exercising his liberty to use the highway on the basis that he may be tempted to invade the 'legitimate interest' of the plaintiff if he were allowed to approach the vicinity of the plaintiff's home. ${ }^{118}$ In this latter case the starting point was the relationship between the power of the High Court to grant and injunction ${ }^{119}$ and the 'need to protect the legitimate interests of those who have invoked its jurisdiction. ${ }^{120}$ Once again the defendant's 'right' to use the highway was reduced to an interest with the result that the case became one of 'two interests to be reconciled.' The reconciliation was then achieved by raising the plaintiff's 'legitimate interest' to the status of a right and to reduce the defendant's to that of a 'liberty', which 'must be respected up to the point at which his conduct infringes, or threatens to infringe, the rights of the plaintiff.' ${ }^{121}$ Finally the liberty and right dichotomy was reduced to one of mutual legitimate interests: in restraining the defendant from temptation the court was not only acting 'in the plaintiff's interest,' but also, 'indirectly, the defendant's. ${ }^{122}$ None of this is to suggest that the Court of Appeal was wrong to grant an injunction on the facts of this case. The point is simply that the source of the law is in the circularity of the reasoning and in the manipulation of concepts like 'interest' and 'right'. There are occasions, in other words, where such bootstrap reasoning can amount to law-making in way that has little to do with the application of rules. The source of law in this case was an 'interest', but an interest that existed as much in the reasoning process as in any social reality. ${ }^{123}$ Ex iure utilitas oritur.

\section{Damages and Interests}

We have seen that interest attaches to - or is orientated towards - an actio in two main ways. It provides a formal link between persona and actio for the purposes of actionability and the role here is essentially procedural. It can also act as a substitute 'right', where its role is to provide a substantive dimension to the availability of a remedy. Does the plaintiff have a legitimate interest in need of protection by the court?

\subsection{Categorizing Harm}

There is however a third, although not unrelated, way in which an interest attaches to a remedy. In damages actions the notion of an interest is used as a

117 See e.g. Gulf Oil (GB) Ltd v. Page [1987] Ch. 327.

118 Burris v. Azadani [1995] 1 WLR 1372.

119 Senior Courts Act 1981 s 37(1).

120 Sir Thomas Bingham MR at 1377.

121 Ibid., at 1380.

122 Ibid., at 1381.

123 For another example, see Blackpool \& Fylde Aero Club Ltd v. Blackpool BC [1990] 1 WLR 1195 discussed in Samuel 2016, at 84-88. 
means of giving expression to, and categorizing, different types of harm suffered by a plaintiff. This damages role has been well described by the late Tony Weir:

'To cause harm means to have an adverse effect on something good. There are several good things in life, such as liberty, bodily integrity, land, possessions, reputation, wealth, privacy, dignity, perhaps even life itself. Lawyers call these goods "interests." These interests are all good, but they are not all equally good. This is evident when they come into conflict (one may jettison cargo to save passengers, but not vice versa, and one may detain a thing, but not a person, as security for a debt). Because these interests are not equally good, the protection afforded to them by the law is not equal; the law protects the better interests better: murder and rape are, after all, more serious crimes than theft. Accordingly, the better the interest invaded, the more readily does the law give compensation for the ensuing harm.' ${ }^{124}$

One can see from this passage why it is tempting to reduce the whole of the law to a matter of 'interests'. ${ }^{125}$ Law is about the protection of 'goods', or the avoidance of harm, and these goods or harm can be divided up, as Weir observed, into interests. Again this is an analysis that has its foundation in Roman law. In an action for the wrongful killing of a slave, the question arose as to the amount of damages that should be payable to the owner: is it just the value of the slave as a thing or is the owner entitled to a value based on the owner's 'interest' in the slave not being killed? The response was in favour of the latter: et hoc iure utimur, ut eius quod interest fiat aestimatio. ${ }^{126}$

This Roman contribution to the law of damages was of importance for two reasons. First, it provided a 'scientific' means of assessing compensation: damages would be payable only if an interest could be identified and valued. ${ }^{127}$ 'Interest', in other words, was the means by which one could link descriptive categories of harm to normative principles of what a defendant ought to pay. Second, it provided a means of giving concrete expression to intangible 'goods', such as loss of an expected profit, ${ }^{128}$ or intangible 'harms', such as depreciation of a collective group of objects through the destruction of a single item. ${ }^{129}$ 'Interest' in this sense became a form of property, an intangible thing (res incorporalis) that in turn endowed the whole idea of an obligation with its proprietary character. ${ }^{130}$ These ideas in turn helped transform the law of delict (tort) from a quasi-criminal law of actions, where a person who had caused harm paid a fine or penalty, to a law of actions founded on a relationship between two individuals where the idea was to 
re-establish harmony between two patrimonies. The development of the notion of an 'interest', it could be said, was synonymous with the development of a more sophisticated private law. ${ }^{131}$

\subsection{Debt, Damages and Interest}

These Roman developments went far in transforming the notion of an interest from being an analytical device attached to the actio to a form of property - or at least 'value' - seemingly capable of existing independently from the remedy. This is most evident perhaps with respect to a claim for a debt. At one level this is simply an entitlement to a remedy, but at another level it is a 'thing', that is to say an asset to be entered as a credit in the creditor's patrimony. In modern common law a debt is a form of property aptly entitled a 'thing in action' (chose in action) and this is one reason why Lord Denning MR was able to conclude that a third party - who according to the established law could obtain no 'rights' from a contract between two others - was entitled to enforce her right to a debt even though she was not a party to the contract creating the debt. ${ }^{132}$ Moreover, she was entitled to sue because she had a 'legitimate interest' to enforce it. ${ }^{133}$ Of course, a right to damages for a slave wrongfully killed or stolen by the defendant might not as such be as much of a res as the slave had been when alive or in the claimant's possession. But metaphysically speaking the right to damages comes very close to being a form of property in itself. Both are capable of being valued in monetary terms and thus both are able to be called 'interests', as we have seen from Tony Weir's observation. In fact this reduction of physical things to mere interests is post-Roman since it is clear that the Roman jurists distinguished between the thing itself (res) and the interest (id quod interest), which attached to it. ${ }^{134}$ And one might note, also, how Weir himself advocated that tort lawyers should continue to distinguish between physical things and money. The 'deference of lawyers to economists,' he lamented, 'is one of the most chilling examples of trahison des clercs in the late twentieth century. ${ }^{135}$ Needless to say, the central concept used in economics is the notion of an interest. ${ }^{136}$

'Legitimate interest' may therefore be a means of stimulating a remedy in situations where there was no legal 'right'. The classic example is where one person is able to obtain damages for the invasion of an interest attaching to another person. This is a problem that can arise as a result of what civil lawyers call the relative

131 Lawson 1950, at 59-60.

132 Beswick v. Beswick [1966] Ch. 538 (CA); but cf. [1968] AC 58.

133 'Where a contract is made for the benefit of a third person who has a legitimate interest to enforce it, it can be enforced by the third party in the name of the contracting party or jointly with him or, if he refuses to join, by adding him as a defendant. In that sense, and it is a very real sense, the third person has a right arising by way of contract. He has an interest which will be protected by law.... It is different when a third person has no legitimate interest, as when... he is seeking to rely, not on any right given to him by the contract, but on an exemption clause': Beswick v. Beswick [1966] Ch 538, 557; cf. [1968] AC 58.

134 D.9.2.21.2; D.47.2.27pr-2; D.47.2.50pr. And see Zimmermann 1996, at 826-827.

135 Weir 1967, at 7.

136 Leroux and Marciano 1998. 
effect of contract (or privity of contract in the common law). Thus in Roman law, where a party promised for something to be given or done on behalf of another, no binding obligation arose since each party must promise only for himself. ${ }^{137}$ The empirical basis for this lack of an obligation was quite clearly stated to be the absence of any interest; it is of no interest to a promisor that something be done in the interest of another. ${ }^{138}$ However, the logic of this empirical thesis is that if there was an interest in respect both of the promisor and of the third party, then there ought to be an enforceable obligation. Now although the Romans themselves appear to have gone some way in accepting this logic, ${ }^{139}$ the procedural technicalities of the Roman stipulation nevertheless resulted in the third party not having an actio and this could prima facie give rise to an unprotected interest. ${ }^{140}$ The question arose therefore as to how one might indirectly give expression to such an interest. The problem was not insoluble and one way or another some third parties, both in Roman law itself and in the later civil law, were allowed to sue until, in the end, the alteri stipulari nemo potest concept was itself abandoned. ${ }^{141}$ Nevertheless, what is important about this Roman law experience is the role assumed by the notion of an interest and the relationship between this concept and the availability of an actio. Interest became the key concept not just with regard to the development of the alteri stipulari rule itself, but equally with respect to its exceptions and ultimate disappearance. ${ }^{142}$

\section{Penalties and Interests}

Mention has already been made of the role of an interest in a claim for debt rather than damages. However, a quite recent case indicates how the notion of an interest can play a vital role in deciding whether or not a clause in a contract imposing a debt liability on a party who fails to conform to certain strict contractual terms is a penalty or not. ${ }^{143}$

\subsection{Penalty versus Legitimate Interest}

The case involved an action in debt for GBP 85 by a car parking company against the owner of a car who had overstayed the two-hour free car parking limit at a retail car park. The owner of the car argued that the debt was unenforceable either because it was a penalty or because it was an unfair term in a consumer contract. The Supreme Court held that the debt was valid. Lord Neuberger reviewed the law on penalty clauses and concluded that this area of law had 'become the prisoner of

142 For a similar problem in English law see Jackson v. Horizon Holidays Ltd [1975] 1 WLR 1468.

143 ParkingEye Ltd v. Beavis [2015] UKSC 67. 
Geoffrey Samuel

artificial categorisation, itself the result of unsatisfactory distinctions: between a penalty and genuine pre-estimate of loss, and between a genuine pre-estimate of loss and a deterrent. ${ }^{144}$ He then asserted that:

'The true test is whether the impugned provision is a secondary obligation which imposes a detriment on the contract-breaker out of all proportion to any legitimate interest of the innocent party in the enforcement of the primary obligation. The innocent party can have no proper interest in simply punishing the defaulter. His interest is in performance or in some appropriate alternative to performance. In the case of a straightforward damages clause, that interest will rarely extend beyond compensation for the breach, and we therefore expect that Lord Dunedin's four tests would usually be perfectly adequate to determine its validity. But compensation is not necessarily the only legitimate interest that the innocent party may have in the performance of the defaulter's primary obligations. ${ }^{145}$

The key notion here is, then, that of a 'legitimate interest'. Lord Neuberger subsequently concluded that although the $£ 85$ charge engaged the penalty rule, the amount was not actually a penalty because the car parking company 'had a legitimate interest in charging them which extended beyond the recovery of any loss.' And he continued:

'The scheme in operation here (and in many similar car parks) is that the landowner authorises ParkingEye to control access to the car park and to impose the agreed charges, with a view to managing the car park in the interests of the retail outlets, their customers and the public at large. That is an interest of the landowners because (i) they receive a fee from ParkingEye for the right to operate the scheme, and (ii) they lease sites on the retail park to various retailers, for whom the availability of customer parking was a valuable facility. It is an interest of ParkingEye, because it sells its services as the managers of such schemes and meets the costs of doing so from charges for breach of the terms (and if the scheme was run directly by the landowners, the analysis would be no different). ${ }^{146}$

Lord Neuberger did, however, qualify this interest analysis in saying that a car parking company could not charge what it liked. There had to be proportionality between the interests in play and the amount charged. ${ }^{147}$ 


\subsection{Unfairness, Good Faith and Legitimate Interest}

Lord Neuberger said that similar considerations applied to the second argument advanced by the car owner, namely that the term was unenforceable under the Unfair Terms in Consumer Contracts Regulations 1999. The term, he said, was not unfair. It was not unfair 'because ParkingEye and the landlord to whom ParkingEye was providing the service had a legitimate interest in imposing a liability on $\mathrm{Mr}$ Beavis in excess of the damages that would have been recoverable at common law. ${ }^{148}$ Indeed the presence of this legitimate interest prevented the imposition of the clause being contrary to good faith as required by Regulation 5(1) of the 1999 Regulations.

This good faith point is interesting because it is the key expression in the legislative text that, according to Lord Neuberger, prevents the term being unfair. According to Regulation 5(2) a term 'shall always be regarded as not having been individually negotiated where it has been drafted in advance and the consumer has therefore not been able to influence the substance of the term.' This of course suggests that the imposition of the car parking charge decided in advance and not as a result of any negotiations with consumers is prima facie unfair. Indeed its penalty nature - that is to say the fact that it is a sum that is far in excess of any sum in damages payable by way of compensation - would seemingly only add to this unfairness. However, these established consumer 'rights', apparently conferred by the traditional rule against penalties and the 1999 Regulations, have now been defeated by the concept of an interest. If a penalty or seemingly unfair clause can be justified by a 'legitimate interest', the debtor's apparent rights will defer to this interest. In other words the car parking company had a 'right' to a debt that prima facie would be unenforceable because they had a legitimate interest in imposing and enforcing it. The established law of penalties, if not the law on unfair terms, has, it would appear, been completely recast by this new case and its deployment of the notion of an interest. Penalty clauses are no longer automatically unenforceable since they are now subject to the interests in play between not just the contracting parties but possibly a range of third parties as well. ${ }^{149}$

\section{Sectional Interest}

The interests attaching to (or orientated towards) the institutions of persons, of things and of actions do not in truth provide a complete or exhaustive map of legal interests. The notion can find itself being applied to more ephemeral 'things' such as the public, commerce and justice. Legal texts contain, in other words, expressions such as the 'public interest', the 'interests of justice' or the 'commercial interest'. ${ }^{150}$ As Professor Cane has noted, 'we often speak of a person's inter-

148 At para. 107 (emphasis added).

149 In the Beavis case these were the interest of the owner of the car park and other motorists wishing to park in the area.

150 See e.g. Al Rawi v. The Security Services [2012] 1 AC 531. 
ests or of the public interest in a broader sense to mean simply objectives or states of affairs which are, or would be, to the person's or the public's advantage: for example, the public interest in the due administration of justice'. ${ }^{151}$

These broader interests can, of course, be integrated within the institutional system in as much as they could be seen as extensions of the persona or res or just the collectivization of a mass of individual interests. But often they are contrasted with the individual interest. For example, it has been said that the 'criminal trial does not exist to protect private interests'; it 'exists as part of the enforcement of the criminal law in the public interest.' 152 Or, again, there 'may be a public interest in disclosure greater than the private interest in secrecy.' ${ }^{153}$

\subsection{Private Rights and the Public Interest}

Sometimes these broader interests can conflict and the court then has to walk a delicate tightrope between, say, the economic and political pressures. ${ }^{154}$ In one nuisance case the judge said:

'The problem with putting the public interest into the scales when deciding whether a nuisance exists, is simply that if the answer is no, not because the claimant is being over sensitive, but because his private rights must be subjugated to the public interest, it might well be unjust that he should suffer the damage for the benefit of all. If it is to be held that there is no nuisance, there can be no remedy at common law. As this case illustrates, the greater the public interest, the greater may be the interference. If public interest is considered at the remedy stage and since the court has a discretion, the nuisance may continue but the public, in one way or another, pays for its own benefit.' ${ }^{155}$

One can see clearly in this extract how the notion of an interest can have an important role to play in legal reasoning. Of course, not all the cases are analysed directly using the concept of an interest, but the notion is often there in the background. ${ }^{156}$ Moreover, the notion itself can be very problematic. Those who combine in order to threaten commercial or business interests may find themselves being accused of causing harm to the public interest, ${ }^{157}$ while the business

151 Cane 1996, at 4.

152 Lord Hobhouse in Arthur J.S Hall \& Co v. Simons [2002] 1 AC 615, at 745.

153 Baroness Hale in Douglas v. Hello! Ltd (No 3) [2008] 1 AC 1, at para. 307.

154 'It is... apparent that whether or not a particular commercial activity is or is not in the 'public interest' is very much a matter of political judgment... and the courts must be careful not to invade the political field and substitute their own judgment for that of the Minister': per Lord Keith in Rv. Secretary of State for Trade and Industry, Exp Lonrho Plc [1989] 1 WLR 525, at 536.

155 Buckley J in Dennis v. Ministry of Defence [2003] EWHC 793, at para. 46.

156 This is true in Thorne v. Motor Trade Association [1937] A.C. 797 where the primary issue was whether a certain threat amounted to blackmail, but the moral dimension was discussed in relation to the notion of 'business interest'.

157 See e.g. Duport Steels Ltd v. Sirs [1980] 1 WLR 142, at 156-157 per Lord Diplock. 
enterprise, which might appear to be threatening the public interest, may find its activity receiving support on the basis of legitimate commercial interest. ${ }^{158}$

\subsection{Commercial Interest and the Public Interest}

In fact the notion of commercial interest has found its way into the heart of English public law in as much as it has become a 'constitutional' right available to the state. Take for example confidential information. The lack of any formal distinction between public and private law has led to government information being protected on the ground of 'ownership' and 'privacy'159 and private sector information being protected in the face of a strong public health interest. ${ }^{160}$ To expose on television to the general public that a certain drug might be dangerous would, according to one appeal judge, be a 'betrayal of business confidences.'161 Again the central concept in these kinds of cases is the notion of an interest. Confidential information is now a matter of two distinct 'interests', namely privacy and secrecy ${ }^{162}$; but these two interests are in turn subject to the 'public interest', which may on occasions override the private interests. ${ }^{163}$ This battle of interests no doubt has the advantage of giving the judiciary much discretion in these matters. ${ }^{164}$ However, it has to be asked if this 'interest' approach ${ }^{165}$ will be able to withstand the shift towards 'rights' stimulated by the Human Rights Act 1998. ${ }^{166}$ One answer is that the interest approach is very much capable of surviving if the notion of a right itself can effectively be reduced, by sleight of reasoning, to an interest.

Constitutional law can in consequence become subverted by the positive and negative aspects of the commercial interest. ${ }^{167}$ There are great dangers in this subversion. To give just one example, the British Foundry Association was reported to have said, in relation to a Freedom of Information Campaign on the environment, that they doubted whether there is a genuine public demand for environmental information. There is only a demand stimulated 'by pressure groups with little regard for the economic consequences of the fulfilment of their demands.'168

158 See e.g. Camelot Group Plc v. Centaur Communications Ltd [1999] QB 124. See also Thorne v. Motor Trade Association [1937] AC 797.

159 Home Office v. Harman [1981] Q.B. 534, at 557; Att-Gen v. Guardian Newspapers [1987] 1 WLR 1248.

160 Schering Chemicals Ltd v. Falkman Ltd [1982] 1 QB 1. But cf Lion Laboratories Ltd v. Evans [1984] 2 All ER 417.

161 Shaw L.J. in Schering Chemicals Ltd v. Falkman Ltd [1982] 1 QB 1, 27.

162 Lord Nicholls in Douglas v. Hello! Ltd (No 3) [2008] 1 AC 1, at para. 255.

163 See now Defamation Act 2013 s 4.

164 One commentator has noted: 'Media lawyers know that a judge's voicing of respect for freedom of expression is usually the precursor to a judgment significantly curtailing that right': Tench 2001, at 10. However see Al Rawi v. The Security Services [2012] 1 AC 531.

165 See e.g. Lord Lowry in X Ltd v. Morgan-Grampian (Publishers) Ltd [1991] 1 AC 1, at 55.

166 Goodwin v. UK (1996) 22 EHRR 123.

167 However, see now Defamation Act 2013.

168 The Observer 16 July 1989, at 4. 
Here one can see that the Association was advancing the economic or commercial interest over what might be called the environmental interest.

\subsection{Environmental Interest}

Yet what is interesting about the environmental interest is that it raises the question of the possibility of an interest attaching to a group of humans - a diffuse persona - who do not as yet exist. In other words, how should the law accommodate the interests of future generations? Today this is a fundamental debate in politics in the face of climate change. Where does the public interest lie? Does the immediate economic argument prove to be a more important public interest than the environmental argument? Even for lawyers this debate cannot really be resolved using the concept of a right, if only because it is not at all clear if this is an issue for civil, constitutional or commercial law. The key concept is the notion of an interest.

However, in this debate the interest cannot easily be attached to a specific persona; it is attached to the notion of 'environment', which may be seen in two principal ways. It could be seen as part of a larger public interest and thus attaches to the populus as a whole or to, say, an agency of the state such as a 'Ministry for the Environment'. Or it could be seen as a form of 'property' and thus become a kind of property interest. Each person has an interest in a healthy environment, this latter notion being seen as something capable of forming a claim in law. No doubt if the courts were to recognize that a healthy environment was something that could form the object of a claim, the notion of an environmental interest would gradually transform into a right.

\section{Mediating Role of an Interest}

Accordingly an interest is a key concept because it has the capability of playing a mediating role. It is this mediating role that links the notion not just to the persona, res and actio structure of legal thought but also to legal reasoning. It is a link between substantive law, procedure and legal argumentation and justification.

\subsection{Deconstructing and Reconstructing Facts}

Sometimes this role can be positive, but it can sometimes be negative as well. In Macaura $v$ Northern Assurance $C{ }^{169}$ the plaintiff sold his timber assets to his 'one man' company in return for all its shares and then, in his own name, took out fire insurance on the timber assets. After a fire that destroyed the timber, the plaintiff tried to claim on the policy, but the insurance company successfully resisted the claim on the ground that he personally had no 'insurable interest' in the assets of the company. His only res were the shares. This seems a strange decision when viewed from the position of an interest as a descriptive concept since it is clear that 
the shareholder had a very real interest in the assets of the company just as a parent has an interest in the school grounds where his or her child is being educated. No doubt the decision can be justified in the narrow terms of insurance law, yet it indicates how interest can act as a negative exclusionary device even in private law. Interest is a means by which facts can be viewed holistically (commercial or consumer interests for example) or in individualistically (company and its sole shareholder) and thus is a device that helps shape the pattern of the facts themselves. 'Interest', in other words, mediates not just between persona, res and actio but also between each element that goes to make up the facts.

It is this ability to construct and deconstruct facts that gives the notion of an 'interest' its important dimension as a formal concept. As Professor Ost observes, the notion has the effect of undermining the traditional vision of law and fact. According to this, traditional 'classical model' law is a matter of systematized and hierarchical rules waiting to be applied through the normative syllogism to sets of facts. ${ }^{170}$ When law is viewed from the position of interests, however, this classical model soon breaks down. As a result of the 'subversive' influence of the interest, the distinction between fact and law becomes blurred and relative; facts become normative (and formalized) and rules become descriptive. The whole flow of the law starts to reverse and to double-back on itself while, at the same time, the frontiers between law and other disciplines break down. In the world of interests things are only relative; it is always a matter of weighing one interest against another within a social context where the objectivity of the judgment no longer has much meaning since everything is a matter of negotiation. The individual is swallowed up by the various class interests of rival social groups, which themselves make up the social corps. ${ }^{171}$

\subsection{Diluting Tendency of English Law}

This view of law from the position of an interest is very much at odds with the official portrait of the legal rule in civil law systems, as Professor Ost indicates. Yet it is not, of course, at odds with the common law vision. The English lawyer will have no problem in envisaging law as a matter of induction rather than deduction ('from the bottom up') ${ }^{172}$ or as a system whose frontiers are open to inputs from other disciplines. ${ }^{173}$ There are several reasons for this difference of conceptualization. First, and foremost, the history of the civil law is largely a history of a movement towards 'axiomatized' codes of subjective rights. ${ }^{174}$ According to this classic model the individual is the focal point of law and thus all law is to be

170 This 'classical' model goes back to the Enlightenment view of legal method when law was seen as a system analogous to mathematics and thus to be applied to facts through logic (mos geometricus): see generally Gordley 2013.

171 Ost 1990, at 176.

172 Ibid., at 176.

173 One thinks in particular the influence of economic thinking in Co-operative Insurance Society Ltd v. Argyll Stores Ltd [1998] A.C. 1. Note also the position in family law: In re L (A Child) [2001] 2 W.L.R. 339 at p. 375.

174 See in particular Gordley 2013. See also Villey 2006. 
viewed from the position of the legal subject (persona). ${ }^{175}$ No intermediate groups, as Ost points out, are allowed to perturb this vision of individual rights, which exist as metaphysical conceptions relating one to another through relations of coordination or subordination, never through integration. ${ }^{176}$ The common law remained untouched by the academic systematizing tendency of humanism; the absence of common law faculties, before the end of the nineteenth century, left the common law to be shaped by practice and by a legal doctrine that thought in terms of lists of actions and procedural refinements. ${ }^{177}$ When common lawyers finally came to think in terms of rights, the most powerful theory was one that saw them as legally protected social interests. ${ }^{178}$ Even today, the idea that rights can be 'objects' of legal claims causes difficulty ${ }^{179}$ and the notion of a right is not something that lends itself to abstract definition. ${ }^{180}$ Rights, even when they are recognized, tend on the whole to be only relative and contingent and this, if one follows the Ost analysis of an interest, will effectively reduce the right to an interest. ${ }^{181}$ Rights, even with the incorporation of the European Convention of Human Rights, are things to be negotiated and traded one against another. ${ }^{182}$ 'Rights have as their vocation to juxtapose and to arrange themselves in a hierarchical order,' observes Professor Ost; 'interests on the other hand have the tendency to merge and to dilute themselves.'183

One can certainly see this diluting tendency in the English case law. ${ }^{184}$ Take the Ashworth Hospital case ${ }^{185}$ where the Court of Appeal upheld a decision in which a newspaper was ordered to disclose the name of the hospital employee who had leaked certain medical records of one of the hospital patients. There is no doubt that such a disclosure of medical records amounted to a gross breach of privacy and Lord Phillips MR was of the view that the hospital itself 'had a clear independent interest in retaining their confidentiality.' However, Article 10 of the Convention for the protection of Human Rights and Fundamental Freedoms states that everyone has the right to freedom of expression and that this includes the right 'to receive and impart information and ideas without interference by public authority.' More specifically, Section 10 of the Contempt of Court Act 1981 lays down that disclosure is not to be ordered save 'in the interests of justice.' One would have thought, therefore, that this fundamental right would have protected the press from having to reveal a source. Indeed, a previous House of Lords

175 This vision is first articulated in a definitive way by Doneau in his Commentarii De Jure Civili.

176 Ost 1990, at 177. One might note also how Pound's classification and analysis of interests (Pound 1959) is rather weak on intermediate group interests.

177 Lobban 1991, at 9.

178 Ionescu 1978, at 143, 148-149.

179 See Jonathan Parker L.J. in Ashurst v. Pollard [2001] 2 WLR 722 at 728.

180 See e.g. In re L (A Child) [2001] 2 WLR 339.

181 Ost 1990, at 176. ParkingEye Ltd v. Beavis [2015] UKSC 67 is surely a good illustration of this point.

182 See e.g. Lord Steyn in Brown v. Stott [2001] 2 WLR 817 at 839.

183 Ost 1990, at 181.

184 And note Tench's comment, Tench 2001.

185 Ashworth Hospital Authority v. MGN Ltd [2001] 1 WLR 515. 
decision ordering disclosure of sources on the basis of the interests of justice was overturned on further appeal to the European Court of Human Rights. ${ }^{186}$ The right of the journalist trumped the interest of justice. Yet on reading Lord Phillips's judgment - in fact on reading the argument for the defence - it becomes clear that the case is not one about rights:

'91. Mr Browne [counsel for the defendants] submitted that in a case such as this the English court has to follow a three-stage test. First it has to decide whether the interests of justice are engaged. Secondly the court has to consider as a fact whether disclosure is necessary to achieve the relevant ends of justice. Finally the court has to weigh, as a matter of discretion, the specific interests of the claimant against the public interest in the protection of journalists' confidential sources. ${ }^{187}$

The central concept here is, quite evidently, that of an interest. One should not be surprised by this since this is the language of negotiation and not vindication. Moreover, this interests approach is closely tied up with the nature of the remedy in issue: the plaintiffs were claiming disclosure through the remedy of discovery of documents and this remedy is essentially procedural. As Lord Reid has pointed out, the 'chief occasion for its being ordered was to assist a party in an existing litigation' but 'this was extended at an early date to assist a person who contemplated litigation.' ${ }^{188}$ The result in the Ashworth case is that the press was not able to rely upon its right to resist the remedy of discovery. It was in effect defeated by a concept, the 'interests of justice', which, as Lord Diplock once stated, is used 'in the technical sense of the administration of justice in the course of legal proceedings in a court of law. ${ }^{189}$ Ubi remedium ibi ius. Or, to put it another way, legal rights are largely a matter of outcomes whose determination has been fought out on the terrain of remedies and procedure. ${ }^{190}$ On this terrain the key concept is not that of a right but of an interest. But, of course, this interest is as formalized a concept as a right, even if it does not have the same inherent normative power, and once formalized it finds itself in the same conceptual world as a right, thus able to take it on, and often, defeat it. ${ }^{191}$

\subsection{Rights versus Interests}

This brings one to the second reason why the common lawyer has less difficulty than the civilian in conceptualizing law from the interest position as analysed by Professor Ost. The common lawyer simply does not reason in terms of rights. To

186 Goodwin v. UK (1996) 22 EHRR. 123; cf X Ltd v. Morgan-Grampian (Publishers) Ltd [1991] 1 AC 1.

187 [2001] 1 WLR at 536 emphasis added.

188 Norwich Pharmacal Co v. Customs and Excise Comrs [1974] AC 133, at 173.

189 Secretary of State for Defence v. Guardian Newspapers Ltd [1985] AC 339, at 350.

190 On this point see Lord Dyson in Al Rawi v. The Security Services [2012] 1 AC 531, at para. 21. See also ParkingEye Ltd v. Beavis [2015] UKSC 67.

191 See e.g. ParkingEye Ltd v. Beavis [2015] UKSC 67. 
an extent this point is evident in a number of the decisions already analysed, but it has equally been dealt with in depth elsewhere. ${ }^{192}$ Suffice it to say, therefore, that when English judges do use the term 'right', they do so usually in a very relative way. 'The word 'rights' is a highly confusing word,' said Ormrod LJ, 'which leads to a great deal of trouble if it is used loosely, particularly when it is used loosely in a court of law.' ${ }^{193}$ One might of course say the same about an 'interest'. But two points need to be made with respect to this latter concept. First, an interest is much more easily identified as a source of reasoning in English law than on the continent where the 'law' is expressed, for the most part, in codes and texts. ${ }^{194}$ Ost, of course, identifies an interest as a viable informal source of law, but in English legal reasoning, as some of the remedy cases show, an interest is virtually a formal building block in the construction of a judgment. ${ }^{195}$

Second, the term interest, being a 'descriptive' concept, functions as much within the facts as within the law and this gives it a certain empirical precision when compared to a right. Such precision may only be viable in the context of a particular set of facts, yet often one interest remains relatively clear vis-à-vis other identified interests within any such factual situation, even if the differences are difficult to resolve. ${ }^{196}$ This endows it with its particular quality in as much as it is capable of being a functionally active notion that brings together legal taxonomy, legal procedure and legal reasoning.

In the civil law, as Professor Ost illustrates, there are plenty of cases where interest has an explicit role in the reasoning and the outcome. Yet 'interest' could equally be used to illuminate those cases where the reasoning, on the surface, seems to be applying more formal normative concepts such as rights and obligations. As Ost observes, any legal system that requires a 'legitimate interest' before one can bring a legal action to vindicate a right must be a system that, in the end, is one founded on interests. ${ }^{197}$ However, the substance of these interests may not always be as empirical as one might think in that the conceptual force of an interest is provided by its relationship with other concepts within the institutional system. And it is this position in the model that goes far in actually defining the apparent empirical substance. It is a notion that prepares facts for the application of the law and makes those facts amenable to legal reasoning. ${ }^{198}$

In contrast the notion of a 'right' in legal discourse is often inadequate as both a reasoning and an explanatory device. A right suggests an absolute normative

192 Samuel 1987.

193 A v. C [1985] FLR 445, at 455. And see also In re L [2001] 2 WLR 339.

194 One could give many examples, but perhaps Thorne v. Motor Trade Association [1937] AC 797, Miller v. Jackson [1977] QB 966 and Burris v. Azadani [1995] 1 WLR 1372 will suffice to support the point.

195 See e.g. Burris v. Azadani [1995] 1 WLR 1372. See also Lord Denning MR's judgment in Miller v. Jackson [1977] QB 966.

196 See e.g. Burris v. Azadani [1995] 1 WLR 1372. See also Lord Dyson in Al Rawi v. The Security Services [2012] 1 AC 531 at paras. 63-64.

197 Ost 1990, at 32.

198 A good example is Lord Denning's contrasting of the public and private interest in Miller v. Jackson [1977] QB 966. 
entitlement that 'trumps' all other claims and obligations; it gives expression to the idea that an owner is entitled to his property - or to enforce a contractual 'right' - irrespective of the social and moral merits of the owner's claim. Yet in most legal disputes, or at least those beyond the law of property and debt, such an all-or-nothing approach is often unrealistic. An ultra-nominalist approach whereby claims are envisaged only from the viewpoint of a vindicating individual operating in a social vacuum is not reflected in the majority of legal decisions, at least in the appeal courts. ${ }^{199}$ What inspires a 'right' is neither a desire for description nor a need for explanation. That is to say, a right is not a concept that can be used to describe the methods employed by the judiciary nor can it be used to explain the process of legal reasoning. Instead it is a concept inspired by ideological legitimization. ${ }^{200}$

No doubt legitimization is as valid an epistemological tool as description or explanation; and so such legitimization can be useful in legal reasoning. But the point to be made, in brief, is that social reality forces legal reasoning to slip from the metaphysical world of normative concepts towards a quasi-normative - that is to say more descriptive - world of legal notions, which can operate within the facts themselves. What helps bind persona with res and with actio is a notion that, like them, functions at one and the same time within the world of fact and the world of norms. This is why the notion of an interest identifies itself both with the Gaian institutional structure and, often, with the concept of a right (rights as socially protected interests). Rights provide legitimization, while interests - seemingly provide description and explanation.

\section{Conclusion}

What, then, are the claims being made with regard to interests? Why should interests be taken more seriously? There are several claims that have been advanced and, hopefully, fully supported by the cases and doctrine discussed or cited. The first is that the notion of an interest can be classified according to the classical institutional scheme of legal thinking (persons, things and actions) and this endows it with some kind of structural coherence. It is not just a matter of an alphabetical list. One is not claiming here that interests need to be rigidly classified according to a formal or metaphysical scheme from which judges can proceed to their solutions through deductive reasoning. It is simply to indicate that interests can be classified according to some rationalized orientations that could aid legal thought. It is to provide a kind of map.

The second claim is that the notion of an interest is a central one at the level of legal reasoning. The cases discussed indicate how it can be used to extend liability

199 And note that even in a case like Ingram v. Little [1961] 1 QB 31, Moorgate Mercantile Ltd v. Twitchings [1977] AC 890 or Shogun Finance Ltd v. Hudson [2004] 1 AC 919 the appeal judges were split.

200 Valade 2001, at 368-369. 
or to restrict it depending upon the facts and the views of the judges involved. The claim is that it provides a much more analytical tool in an epistemological sense than the notion of a right because it is a notion that is informed by the facts themselves - it operates within the facts - but has resonance in the world of law and legal thinking as well.

The third claim is linked to these first two. Because the notion of an interest can be seen to conform to the institutional structure of legal thought and yet it operates also at the level of fact, it has a unique ability to inject legal conceptualism into the facts themselves. It can help make them 'conform' to the law. It is a notion, then, that plays an important role in the relationship between fact and norm.

In summary one might say this. It is this descriptive and explanative ability which forms the key to the central role of an interest in legal reasoning. However, this article has gone further than simply exposing the role of an interest behind many apparent 'rights'; it has shown that the notion of an interest is not something to be understood in terms of a list of different categories of interest defined strictly in terms of their empirical content. It is not a matter of abstracting from legal analysis a public, private, commercial, state, economic, expectation, restitutionary, reliance interest (and so on) and endowing each category of interest with a linguistic definition. It is a question of modelization. That is to say it is a matter of seeing an interest as an important formal relational element that helps begin to represent the complexity of social fact within the structural model of persona, res and actio. It is this model that mediates between fact, law and reasoning and it has been the object of this article to discuss case law examples that illustrate this epistemological thesis. For the ideologist, rights no doubt deserve to be taken more seriously than interests - and indeed there are occasions where this must be so (for example, human rights and, perhaps, property rights). But for the epistemologists the reverse is true. The notion of an interest gives a much more convincing insight into the reasoning of lawyers and judges and that is why it should be taken at least as seriously as rights.

\section{References}

Bergel, J-L. (2012). Théorie générale du droit (5th ed.). Dalloz.

Cadiet, L., Normand, J., \& Mekki, S.A. (2013). Théorie générale du procès (2nd. ed.). Presses Universitaires de France.

Cane, P. (1996). Tort law and economic interests (2nd ed.). Oxford University Press.

Doneau, H. Commentarii De Jure Civili

Dworkin, R. (1977). Taking rights seriously. Duckworth.

Goltzberg, S. (2013). Chaïm Perelman: l'argumentation juridique. Michalon.

Gordley, J. (2013). The jurists: A critical history. Oxford University Press.

Gray, K., \& Gray, S. (1999). Private property and public property. In J. McLean (Ed.), Property and the constitution. Hart.

Gray, K., \& Gray, S. (2003). The rhetoric of reality. In J. Getzler (Ed.), Rationalizing property, equity and trusts. Butterworths.

Hedley, S. (2009). Looking outward or looking inward? Obligations scholarship in the early 21st century. In A. Robertson, \& T.H. Wu (Eds.), The goals of private law. Hart. 
Heineccius, J.C. (1785). Elementa Juris Civilis Secundum Ordinem Pandectarum. Venice. Ionescu, O. (1978). La notion de droit subjectif dans le droit privé. Bruylant.

Jolowicz, J.A. (1983). Protection of diffuse, fragmented and collective interests in civil litigation: English law. Cambridge Law Journal, [1983], 222.

Lawson, F.H. (1950). Negligence in the civil law. Oxford University Press.

Lawson, F.H., \& Rudden, B. (2002). The law of property (3rd ed.). Oxford University Press.

Leroux, A., \& Marciano, A. (1998). La philosophie économique. Presses Universitaires de France.

Lever, J.F. (1961). Means, motives, and interests in the law of torts. In A.G. Guest (Ed.), Oxford essays in jurisprudence. Oxford University Press.

Lobban, M. (1991). The common law and English jurisprudence 1760-1850. Oxford.

Ost, F. (1990). Droit et intérêt: vol 2 - entre le droit et non-droit: l'intérêt. Facultés SaintLouis.

Pound, R. (1959). Jurisprudence: volume III. West.

Rampelberg, R-M. (2005). Repères romains pour le droit européen des contrats. LGDJ.

Rochfeld, J. (2011). Les grandes notions du droit privé. Presses Universitaires de France.

Roland, H., \& Boyer, L. (1986). Adages du droit français (2nd ed.). L'Hermès.

Samuel, G. (1987). 'Le droit subjectif' and English Law. Cambridge Law Journal, [1987], 264

Samuel, G. (1994). The foundations of legal reasoning. Maklu.

Samuel, G. (1997). Classification of obligations and the impact of constructivist epistemologies. Legal Studies, 17, 448

Samuel, G. (2004). The notion of an interest as a formal concept in English and in comparative law. In G. Canivet, M. Andenas, \& D. Fairgrieve (Eds.), Comparative law before the courts. British Institute of International and Comparative Law.

Samuel, G. (2013). A short introduction to the common law. Edward Elgar.

Samuel, G. (2014). An introduction to comparative law theory and method. Hart Publishing.

Samuel, G. (2016). A short introduction to judging and to legal reasoning. Edward Elgar.

Stein, P. (1983). The development of the institutional system. In P. Stein, \& A. Lewis (Eds.), Studies in Justinian's institutes in memory of J. A. C. Thomas. Sweet \& Maxwell.

Stein, P. (1988). The character and influence of the Roman civil law. Hambledon.

Stevens, R. (2009). The conflict of rights. In A. Robertson, \& T.H. Wu (Eds.), The goals of private law. Hart.

Tench, D. (2001). Media Guardian, p. 10.

Valade, B. (2001). De l'explication dans les sciences sociales: holisme et individualisme. In J-M. Berthelot (Ed.), Épistémologie des sciences sociales. Presses Universitaires de France.

Villey, M. (2006). La formation de la pensée juridique moderne. Presses Universitaires de France, Quadrige.

von Jhering, R. (1913). (trans I. Husik). Law as a means to an end. Boston.

Waddams, S. (2003). Dimensions of private law: categories and concepts in Anglo-American legal reasoning. Cambridge University Press.

Weir, T. (1967). A casebook on tort. Sweet \& Maxwell.

Weir, T. (2004). A casebook on tort (10th ed.). Sweet \& Maxwell.

Zimmermann, R. (1996). The law of obligations: Roman foundations of the civilian tradition. Oxford. 